\title{
A REVIEW OF THE TAXATION REGULATORY DOCUMENTS ADOPTED IN FEBRUARY-MARCH 2015
}

\author{
L.Anisimova
}

Russia's government began to implement its anti-crisis plan for 2015 by adopting specific documents in the period under review. Despite its pro-market rhetorical statements, the government has so far taken no substantial steps towards economic reforms and enhancing the business environment in the country. At a meeting with representatives of the Russian Union of Industrialists and Entrepreneurs (RSPP), President Putin warned the businessmen that their assets in foreign jurisdictions might be frozen; confirmed the federal government's endeavor to grant an amnesty to the capital returned to Russia; and agreed with the RSPP point of view on the need to synchronize the coming into effect of a capital amnesty bill with the Tax Code provisions concerning the taxation of the income of controlled foreign corporations (CFCS) and the submission of respective notifications to Russia's tax authorities ${ }^{1}$. A document, which invites some questions, concerning draft amendments to the Federal Budget Law for 2015 and the Planning Period of 2016-2017 was submitted to the State Duma for consideration.

In the period under review, some of the developed measures of anti-crisis regulation were implemented through the adoption of regulatory documents.

1. To increase the capitalization of the banking sector is a key measure among the measures aimed at maintaining the financial stabilization in Russia's economy. The fiscal support is provided through the Federal Law of 08.03.2015 No. 32-FZ "Concerning the Amendments to Part 2 of the Tax Code of the Russian Federation". The following was exempted from taxation: the incomes payable to the Deposit Insurance Agency (DIA) on operations aimed at maintaining the sustainability of the banking system ${ }^{2}$, including the

1 "Putin supported MinFin proposals on capital amnesty draft laws". Ekonomika i biznes, 25 March. Available on tass.ru/ekonomika/1854649 The definition of CFC is provided in Paragraph 1 and Article 2. 25.13 of the Tax Code of Russia; taxable incomes (profits) of CFCs are defined in Paragraph 7 thereof; the controlling person is defined in Paragraph 3, Article 25.13 (the controlling person may be an individual or a legal entity having a stake in CFC(s) of more than $25 \%$ or more than $10 \%$, provided that Russian residents' total stake in a company is more than $50 \%$ ). Resident Russian taxpayers recognized as persons controlling a foreign corporation must notify until 1.04.2015 Russia's tax authorities of holding a stake in CFC(s) pursuant to Article 4.4 of the Federal Law No. 376-FZ of 24.11.2014. Persons whose obligation to notify arose after Article 25.14 came into force, shall submit such notification to the tax authority situated at the place of their registration within a period not later than 20 March of the year following the fiscal period during which the share of profit of the controlled foreign corporation is to be recognized in the books of the controlling person. The notification procedure is expected to be postponed, as the RSPP suggested, until H2 2015, when a capital amnesty bill is to be presumably adopted.

2 Article 3 of the Federal Law of 29.12.2014 No. 451-FZ "Concerning Amendments to Article 11 of the Federal Law "Concerning the Insurance of Individuals' Bank Deposits in the Banks of the Russian Federation and Article 46 of the Federal Law "Concerning the Central Bank of the Russian Federation" provides the possibility for the $A C B$ to transfer the received by the $A C B$ coupon yield on Russian government bonds (OFZs) which the DIA received as asset contribution from the state; the interest on subordinated loan agreements concluded with banks; the penalties received from banks, - in the case when the DIA transfers specific incomes to the federal budget. At the same time, the funds transferred to the federal budget are not recognized as the DIA's expense for the assessment of the profit income tax base.

The same law specified the terms of recognizing the debenture interest as expense for the purpose of the "fine capitalization" set forth in Article 269 of the Tax Code of Russia (TC of Russia), while undertaking transactions between affiliated persons. As a reminder, this rule allows one to recognize as dividends a part of the interest which an affiliated person pays above the controlled amount to other affiliated person and not to deduct the interest above the controlled amount for the assessment of the profit income tax base.

According to the adopted amendments and updates to the TC of Russia, the expense incurred on ruble-denominated obligations arising from the transaction between affiliated persons in the period between 1.01.2015 and 31.12.2015 may be accrued to an interest of 0 to $180 \%$ of the central bank key interest rate, while the expense on obligations arising in the period after 1.01 .2016 may be accrued to 75 to $125 \%$ of the foregoing interest rate. The cap of the interest accrued to the expense during December 2014 (when the ruble's exchange rate plunged), if there are no debentures owed to Russian organizations, is allowed to equal an amount not higher than the central bank

Agency as asset (government bonds) contribution of the Russian Federation to the subordinated loans of a commercial bank (loans secured by the shares in the borrowing bank and treated as bank equity) to maintain the liquidity of the bank. 
refinancing rate, increased by 3.5 times, when a rubledenominated debenture is effectuated.

2. The Federal Law of 08.03.2015 No. 49-FZ "Concerning Amendments to Part 1 of The Tax Code of the Russian Federation" broadens the powers vested with the Federal Tax Service of the Russian Federation (FTS of Russia) to grant a deferral (installment) for the payment of federal taxes and levies. In particular, the provisions of the TC of Russia allowing Russia's government to make decisions on rescheduling the dates of payment of federal taxes and levies credited to the federal budget, ceased to be in force. From now on, such decisions as well as decisions on granting a deferral of up to three years for the payment of federal taxes, penalties and fines will be within the scope of competence of the Federal Tax Service.

3. The Federal Law of 08.03.2015 No. 25-FZ "Concerning the Suspension of the Effect of Certain Provisions of the Budget Code of the Russian Federation" suspended the effect of certain provisions, in particular, the provision which requires that not later than within three months state (municipal) programs be brought in compliance with the budget law. The point is that some programs may well be suspended, without being revoked, because of insufficient financing. Suspended was the effect of the provision of the Budget Code of Russia (BC of Russia) which requires the submission of the anticipated socio-economic development of the country in the current year and the updated socio-economic development forecast in the planning period along with the draft law of amendments to the federal budget for the current fiscal and planning period to the State Duma of Russia for consideration. Perhaps, Russia's government considers that it would be unreasonable to prepare more than one version of estimates given the unsettled external environment and the ruble's exchange rate. Suspended was the effect of the provision allowing the Finance Ministry of Russia to decide, without amending the applicable budget law, on making adjustments in the consolidated quarterly budget breakdown, which concern changes in the composition and/or powers of chief controllers (of subordinate government bodies); the coming into force of laws granting subventions to cover the spending of regional government bodies (local governments); the enforcement of court orders on recoveries from the funds of budgets of the Russian budget system; the spending of the resources of reserve funds, etc. It can be understood that under the circumstances it would be unreasonable to authorize the Finance Ministry of Russia to use the reserves. The same law puts on hold the possibility to modify the content of the consolidated quarterly budget breakdown, which concerns state off-budget funds for 2016 and 2017, puts hold on limits imposed by the chief budget controller in 2016 and 2017, allows the conclusion of agreements on behalf of the Russian Federation on supplies of goods to be paid in 2016 or resulting in expense obligations beyond the expiration dates of approved limits on budget commitments exclusively by the decision of Russia's government.

The persons in charge of state programs must submit until 1 October 2015 draft projects of the state programs of the Russian Federation.

4. The Federal Law of 8.03.2015 No. 21-FZ adopted "The Code of Administrative Court Procedure of the Russian Federation". The Code regulates the judicial procedure at the Supreme Court of the Russian Federation (SC of Russia) and general jurisdiction courts for administrative cases on abridged or contested rights, freedoms and legitimate interests of the nationals and organizations (for example, Russia's nationals right to vote, right to participate in referendum), other administrative cases arising from administrative and other public legal relationships and rela-ting to the exercise of legality judicial control and the propriety of government and other public powers, including the challenging of regulations, decisions, actions (omissions) of state government bodies, other government bodies, military authorities, local government authorities, public officers, civil servants (municipal servants), non-profit organizations exercising the assumed public administration function (for example, the high judge qualification examination board and examination boards of the constituent territories of the Russian Federation), etc.

We suppose that the adoption of the Code has facilitated the creation of legal mechanics and procedure for bringing actions against state government bodies, public administrations bodies, challenging regulations, decisions, actions (omissions) of public servants, protecting the constitutional rights of Russia's nationals from administrative and bureaucratic caprices.

The Code took effect under the Federal Law of 8.03.2015 No. 22-FZ. According to Article 4 thereof, the hearing of cases on recovery claims against physical persons on compulsory payments and sanctions must be conducted pursuant to the procedure provided for by the Code. It is, however, the law enforcement practice that will show whether the Code has eliminated the conflict between the two branches of law - the tax law (the authorized body is the Federal Tax Service of the Russian Federation) and the criminal law (the authorized body is the Investigative Committee of the Russian Federation) - concerning the introduction of sanctions for tax abuse.

5. The Russian Government Executive Order of 12 March 2015 No. 214 adopted as part of the anti-cri- 
sis measures the Rules for granting federal budget subsidies in 2015 to industrial enterprises so that they may cove a part of the costs incurred in 2015 on the Payment of interest on loans acquired from Russian credit institutions and the State Corporation "Bank for Development and Foreign Economic Affairs (Vnesheconombank)", as well as international financial organizations established under international agreements to which the Russian Federation is a party, in order to accumulate the current assets and/or finance day-to-day operations.

Pursuant to the approved Rules, the Finance Ministry of Russia was commissioned to appropriate $\mathrm{Rb} 20 \mathrm{bn}$ of budget resources, including $\mathrm{Rb} 5 \mathrm{bn}$ in Q1 2015, to the Ministry of Industry and Trade (MinPromTorg) to grant subsidies to industrial enterprises in order to reimburse their costs on the interest on loans denominated in rubles granted by Russian banks and Vnesheconombank, international financial organizations in order to accumulate their current assets and/or finance day-to-day operations.

However, while the interest on loans denominated in foreign currencies indeed might have caused losses for Russian manufacturers due to the plunged ruble's exchange rate, there is no quite clear economic sense in reimbursing the interest on loans denominated in rubles raised by manufacturers from Russian credit institutions, Vnesheconombank and international financial organizations. Upon the drastic depreciation of the ruble's exchange rate, Russia's central bank intentionally lifted the key interest rate in order to make liquidity less available for commercial banks. Banks in turn increased their loan interest rates, because their liquidity had acquired a new value. What happened next is that Russia's government upped and paid to banks the interest difference at the expense of the resources collected as taxes. In other words, individuals and manufacturers simply gave away a certain amount of money directly to bankers rather than paid for the increased interest rates accrued by the manufacturers to the costs of production of goods (works, services). For no obvious reason the banking system is not supported using the reserves in the system itself (which are accumulated in the course of banking business), instead it is supported at the expense of budget tax revenues collected from individuals and other manufacturers, which are supposed to be spent otherwise, thus making the target recipients run short of resources.

Instead of making an ordinary credit agreement between manufacturers and a bank, an entire system of public control over the spending of subsidies of new type has been set up. A big body of bureaucrats will be involved in monitoring the observance of the Rules for granting subsidies: appropriation of subsidies, documents that confirm a proper appropriation of subsi- dies, все ли duly and timely issuance of certificates, etc. It has finally appeared that strict business relations between the bank and the borrower have been turned into direct public management and control. And this has happened at the very height of the financial crisis. We regret to say that such policies will end up with a budget deficit - banks simply accrued the subsidized interest rates to income (they made money from thin air, i.e. the central bank decision to lift the key interest rate) and will use the money in their business operations $^{1}$. Thereafter, they will use the same money to finance credits and loans which Russia's government will raise in the market in order to cover the budget deficit - and make profit on the interest rates once again.

6. It seems to be more reasonable in times of crisis to grant budget subsidies to meet the final consumer demand rather than reimburse the manufacturers' costs.

Out point of view is based on the fact that tax revenues of the budget system are ultimately generated through final consumers of goods (works, services), i.e. physical persons, irrespective of whether they are indirect taxes (the value added tax (VAT), excise taxes) or direct taxes (the personal income tax, the profit tax, the property tax). In any case, buying goods (works, services) for the consumption purpose, individuals pay market prices for such goods into which manufacturers of goods (works, services) embed all costs and compulsory payments due by the manufacturers. Therefore, the provision of budget subsidies to final consumers is only a way of redistributing incomes among various groups of people. At the same time, this is real effective demand (although it is altered by subsidizing) which shapes the market structure of the production.

Subsidies of these types include $\mathrm{Rb} 8,8 \mathrm{bn}$ worth subsidies granted to the OJSC Russian Railways (RZHD) under the Russian Government Executive Order of 25.02.2015 No. 166 "Concerning Amendments to the Executive Order of the Government of the Russian Federation of 17 October 2011 No. 844" for reimbursing the lost incomes due to the application of the preferential (reduced) tariff for passengers of commuter trains; $\mathrm{Rb} 20 \mathrm{bn}$ worth subsidies granted under the Rules for the provision of federal budget subsidies to Russian credit institutions and the Open Joint-Stock Company Agency for Housing Mortgage Lending for reimbursing the lost returns on provided (acquired) housing (mortgage) loans (credits), as approved by the Russian Government Resolution dated 13.03.2015 No. 220.

The provision of budget subsidies to reimburse individuals' costs on buying goods (works, services) should

1 Indeed, banks were actually compensated at the expense of the other market participants for their losses caused by the depreciation of the ruble's exchange rate. 
be approached in a very delicate manner, because taxes must be used first of all for addressing social issues and enhancing the living standards of socially vulnerable groups of persons. The substitution of the objectives of taxation with the intention to finance the development of given industries may result in increasing the wellbeing of higher income persons at the expense of lower-income persons, which, for example, is the case with subsidizing the interest on housing (mortgage) loans.

7. The anti-crisis measures include the granting of state guarantees for the obligations owed by manufacturers. This issue was settled as early as 2012 under the Russian Government Executive Order of 14.08.2012 No. 825 "Concerning the Procedure for the provision in 2012-2014 of state guarantees of the Russian Federation on loans or bonded loans raised by legal entities for the purposes established by the Government of the Russian Federation as part of the measures aimed at enhancing a sustainable economic development amid the deteriorating situation in the financial markets". The foregoing Procedure was amended and updated by the Russian Government Executive Order of 4 March 2015 No. 189. It will stay in effect in 2015.

Since the adopted Procedure had a significant provision removed as early as September 2014, under which it was possible to grant state guarantees on obligations denominated in U.S. dollars, the recent amendments provided no such critical and important decisions, being reduced to basically drafting amendments, more details on procedural matters, changes in the effective period of guarantees. In particular, it is specified that in 2015 state guarantees will be granted to ensure the performance of the principal's obligations whose maturity is due after 1 January 2018 under the terms of a credit agreement.

8. We cannot overlook the scheme of receiving pseudo-subsidies by manufacturers falling under certain categories, which is not recognized as budget spending and left outside the scope of budget process, which, in our opinion, is inappropriate while we are facing financial hardship and developing special anticrisis measures. Regretfully, the situation was neither contested by the financial authorities, nor any explanations were given of the same. For instance, the Letters of the FTS of Russia of 27.02.2015 No. GD-43/3117; GD-4-3/3118; GD-4-3/3119; GD-4-3/3120 clarify the issue "Concerning the Application for the Excise Tax Purposes of the Provisions of the Federal Law of 24.11.2014 No. 366-FZ".

It is our opinion that the excise reimbursement scheme introduced by the Federal Law of 24.11.2014 No. 366-FZ into the TC of Russia, which was estab- lished by the TC of Russia for operations of refining the straight-run gasoline in the case of using the produced straight-run gasoline for the production of petrochemical products (production of benzene, paraxylene, ortoxylene), is a way of veiled reception of a budget subsidy by payers beyond the federal budget law for the ensuing financial year and the planning period and without observing the requirements for being eligible for budget subsidies set forth in the BC of Russia. As a reminder, under Paragraph 15, Article 200 of the TC of Russia, while undertaking the foregoing operations, the excise taxpayer may deduct the previously paid amount of the excise tax multiplied by the multiplying coefficient established by type of operations (a multiplying coefficient of 1.37 or 2.88 is applied in the period of 1 January 2015 thru 31 December 2015). In other words, the point is actually that the TC of Russia requires that tax authorities effect payments in favor of taxpayers which exceed the obligations executed by these taxpayers. It is our opinion that the constitutional principle of taxation as part of the TC of Russia has been breached, because some of the taxes are paid to certain third party business entities, instead of being transferred to the budget. The created situation requires a legal research.

The following regulatory acts concerning the assessment of the tax base and the amount of tax liabilities are worth noting:

9. The Federal Law of 08.03.2015 No. 42-FZ introduced significant amendments to Part 1 of the Civil Code of Russia. The amendments concern the law of obligations (in particular, statutory innovations were introduced concerning legitimate interest rates, alternative and optional obligation, etc.); contractual relations (in particular, statutory innovations were introduced concerning the due date, unilateral repudiation, forfeit reduction, recovery of losses, calculation of the interest accrued on the use of other people's money); security provision measures (statutory innovations concern an independent guarantee, security payment, etc.).

10. The Finance Ministry Letter of 03.03.2015 No. 03-03-10/11054 and the FTS Letter of 17.03.2015 No. GD-4-3/4211 clarify the coming into force on 1.01.2016 of agreements on the establishment of consolidated groups of taxpayers (CGT) registered with tax authorities in 2014, as well as the rescheduling of the coming into force of amendments and updates introduced into the agreements on the accession of new members to the group in the period between 2014 and 2015. 